\title{
Odbudowa i rozwój polskiej geografii fizycznej po drugiej wojnie światowej w latach 1945-1980
}

\section{Leszek Starkel}

Instytut Geografii i Przestrzennego Zagospodarowania im. Stanisława Leszczyckiego PAN ul. Św. Jana 22, 31-018 Kraków starkel@zg.pan.krakow.pl

Zarys treści. Autor omawia przebieg odbudowy i rozkwitu polskiej geografii fizycznej po drugiej wojnie w warunkach zdziesiątkowanych kadr, zniszczonych warsztatów pracy, w warunkach zmiany granic państwowych i preferowania ideologii marksistowskiej. Już w latach 1945-1946 następowała odbudowa Polskiego Towarzystwa Geograficznego, które przejęło ster przygotowań nad rozwojem geografii w ramach wydziałów spraw naukowych i spraw dydaktycznych PTG. W warunkach izolacji od współpracy międzynarodowej opracowano program badań naukowych zmierzających do wszechstronnego poznania środowiska geograficznego i zasobów gospodarczych kraju, ukierunkowując je na potrzeby gospodarcze. Przystąpiono do jego realizacji i równocześnie przedstawiono do akceptacji na pierwszym Kongresie Nauki Polskiej w $1951 \mathrm{r}$.

Jesienią 1953 r. z inicjatywy S. Leszczyckiego został utworzony Instytut Geografii PAN, który przejął koordynację najważniejszych programów badawczych obejmujących cały kraj i pracujących identycznymi metodami, co po około 20 latach pozwoliło na publikację syntetycznych opracowań kartograficznych i monografii.

Gdy w 1956 r., po raz pierwszy po wojnie, Polacy wzięli udział w Kongresie Międzynarodowej Unii Geograficznej, a w 1957 r. w Kongresie Międzynarodowej Asocjacji Badań Czwartorzędu INQUA, okazało się, że Polacy wypracowali w kraju oryginalne metody badań i osiągnęli ciekawe wyniki. W efekcie, w ciągu kilku lat zostali powołani na przewodniczących kilku komisji MUG i zaproszeni do zorganizowania VI Kongresu INQUA w Polsce w 1961 r. Rozpoczęła się ożywiona współpraca międzynarodowa. Równocześnie rozwinęły się badania polarne - organizacja wypraw i zakładanie stałych stacji naukowych.

Polacy nie tylko zaczęli uczestniczyć w programach międzynarodowych, ale nawet niektóre z nich inicjowali i im przewodniczyli. Zaczęła też rysować się specjalizacja poszczególnych ośrodków naukowych. Rosnące w skali światowej potrzeby racjonalnej gospodarki kurczącymi się zasobami przyrody i budowania prognoz zmian klimatu, skłoniły także w Polsce różne dziedziny nauk (w tym inżynierskich, biologicznych i innych) do podejmowania tej problematyki. W tej sytuacji geografowie u schyłku lat 70. wystąpili z inicjatywą powołania na następną dekadę dwóch programów międzyresortowych, w tym jednego z zakresu geografii fizycznej (Przemiany środowiska geograficznego Polski). Miały one odnowić warsztat badawczy, dostarczyć opracowań syntetycznych, jak też zapewnić większą integrację ośrodków geograficznych w Polsce.

Słowa kluczowe: geografia polska, lata 1945-1980, odbudowa i rozwój. 


\section{Polskie Towarzystwo Geograficzne liczy szable po wojnie...}

Obchodzimy stulecie powstania Polskiego Towarzystwa Geograficznego, które budowało zręby polskiej geografii w nowym państwie polskim. W jego historii mamy jednak drugi okres odbudowy kraju i naszej nauki po drugiej wojnie światowej w trudnych warunkach zdziesiątkowanych kadr, zniszczonych warsztatów pracy, nowych granic państwa i inwazji ideologii marksistowskiej. Na szczęście ta ostatnia nie była bezpośrednio groźna dla nauk o Ziemi. Znaleźli się ludzie, którzy potrafili się zmobilizować i rozpocząć odbudowę polskiej geografii już w $1945 \mathrm{r}$.

W nowych granicach pozostały jedynie 3 ośrodki uniwersyteckie: Kraków, Poznań i Warszawa. Geografowie Iwowscy przenieśli się do Lublina i Wrocławia, wileńscy - częściowo do nowej uczelni w Toruniu. Powstała nowa uczelnia w Łodzi. Profesor Romer zatrzymał się w Krakowie i habilitował doktorów prawie z całej Polski. Zabrakło przedwojennych liderów: Lencewicza, Pawłowskiego, Smoleńskiego... Niektórzy wyemigrowali.

Już wiosną 1945 r. zaczęły kontaktować się ze sobą oddziały PTG. Ich kolejne zjazdy odbyły się w Warszawie, Lublinie i Krakowie. Przygotowano pierwsze zeszyty Przeglądu Geograficznego i Czasopisma Geograficznego. W czerwcu 1946 r. odbył się pierwszy zjazd PTG w stolicy, na którym, obok pracowników uczelni i szkół, reprezentowane były centralne instytuty badawcze, zwłaszcza związane z geografią fizyczną (Instytut Geologiczny, Instytut Hydrologii i Meteorologii, Wojskowy Instytut Geograficzny). Powołano osobne wydziały: naukowy i dydaktyczny. Liczba członków przekroczyła 1100 osób. Do PTG wstąpili, czujący więź z geografią, geolodzy i meteorolodzy.

Na kolejnym zjeździe w Toruniu (w 1947 r.) dyskutowano nad kierunkami rozwoju polskiej geografii, w tym różnych działów geografii fizycznej. Wymieniono potrzebę opracowywania w terenie szczegółowych map geomorfologicznych, hydrograficznych, przeprowadzenia prac nad regionalizacją fizyczno-geograficzną i opracowania monografii regionów, zwłaszcza tzw. Ziem Odzyskanych. Utworzono osobny zespół do spraw wypraw badawczych, postulując opublikowanie wyników przedwojennych badań w Arktyce i opracowanie programów postulowanych wypraw.

\section{Opracowanie programu badań geograficznych i I Kongres Nauki Polskiej}

Lata 1947-1951 były okresem gorących dyskusji i przygotowania na I Kongres Nauki Polskiej programu rozwoju geografii, który uwzględniał kierunki badawcze (wśród nich priorytetem były badania dla gospodarki narodowej i opracowania syntetyczne - atlasy i monografie), powołanie nowego instytutu w powstającej Polskiej Akademii Nauk i zorganizowanie terenowych stacji badawczych z zakresu geografii fizycznej. Program ten został opracowany przez zespół pod kierunkiem prof. S. Leszczyckiego. W zakresie geografii fizycznej program ten obejmował: 
A. Badania środowiska geograficznego Polski i jego elementów (opracowanie szczegółowych map geomorfologicznych i hydrologicznych całego kraju, synteza klimatu Polski, badania nad erozją gleb);

B. Badania kompleksowe środowiska dla planów regionalnych (regiony przemysłowe, zbiorniki wodne, atlasy województw);

C. Prace nad monografiami, atlasami Polski i świata.

Równocześnie przewidziany był rozdział funkcji między PTG a przyszłymi instytucjami: Instytutem Geografii PAN i Komitetem Nauk Geograficznych PAN. Instytut Geografii PAN miał kierować (lub koordynować) tematy centralne, w których uczestniczyłyby ośrodki uczelniane, miał wydawać Przegląd Geograficzny i prowadzić stacje terenowe. Komitet Nauk Geograficznych PAN miał koordynować programy badawcze i współpracę międzynarodową (kongresy, wyprawy).

Zarówno program naukowy przedstawiony na I Kongresie Nauki Polskiej w 1951 r., jak i powołanie Instytutu Geografii PAN, zostały zaakceptowane do realizacji. Przygotowany i zatwierdzony program nie był jedynie wizją przyszłości, ale bazował w większości na działaniach już podjętych w placówkach uczelnianych i niekiedy wspieranych finansowo przez Polskie Towarzystwo Geograficzne.

Tak było z kartowaniem geomorfologicznym, rozpoczętym już w 1950 r. z asystentami i studentami w Krakowie (M. Klimaszewski) i nieco później w Toruniu (R. Galon). Koncepcja była oryginalna. Mapa prezentowała genezę i wiek form kolorami, co pozwalało odczytać ewolucję rzeźby. Podobnie było z zainicjowanym (również poza oficjalnym programem studiów) kartowaniem powierzchniowych zjawisk hydrologicznych. W Łodzi J. Dylik rejestrował formy i osady peryglacjalne oraz rekonstruował środowisko okresów zimnych, zapraszając na wyjazdy terenowe asystentów z innych ośrodków. Prowadzono też obserwacje mikroklimatyczne na stacjach naukowych należących do PTG.

\section{Powstanie Instytutu Geografii PAN}

W październiku 1953 r. został utworzony Instytut Geografii Polskiej Akademii Nauk, który w myśl koncepcji S. Leszczyckiego, miał prowadzić badania z zakresu najważniejszych dziedzin, służące równocześnie potrzebom gospodarki kraju z zagospodarowaniem przestrzennym na czele. W tym celu miał koordynować programy realizowane przez wszystkie ośrodki naukowe, a kadrę stanowili specjaliści pochodzący niejednokrotnie spoza stolicy. Powstały małe pracownie (często potem przekształcone w Zakłady). W zakresie geografii fizycznej w stolicy zostały utworzone: Zakład Klimatologii (W. Okołowicz, później J. Paszyński) oraz Zakład Geografii Fizycznej Kompleksowej z Pracownią Geografii Jezior (J. Kondracki).

Poza Warszawą powstały 3 pracownie: Geomorfologii i Hydrologii Gór i Wyżyn w Krakowie (M. Klimaszewski), Geomorfologii i Hydrografii Niżu w Toruniu (R. Galon) - obie realizujące szczegółowe mapy geomorfologiczne i hydrologiczne 
Polski - oraz Pracownia Geomorfologii Peryglacjalnej (J. Dylik). Obok tego z Instytutem zostały powiązane terenowe stacje badawcze (należące wcześniej do PTG) w Wojcieszowie, Międzyzdrojach, Mikołajkach i na Hali Gąsienicowej w Tatrach. W następnych latach trzy pierwsze, nie mając konkretnego programu badawczego, zostały zlikwidowane. W ich miejsce wraz z rozwojem monitoringu procesów geomorfologicznych, hydrologicznych i meteorologicznych, powstały stacje karpackie w Szymbarku (w 1966) i Homerce (1971), w dolinie dolnej Wisły w Dobiegniewie (1977) i klimatyczna na Mazowszu w Borowej Górze (1966). Dołączyły one do Hali Gąsienicowej badającej piętrowość procesów w Tatrach. W programie badań Instytutu znalazły się zatem główne tematy programu geografii fizycznej przedstawionego na I Kongresie Nauki Polskiej.

Z grona kończących studia wiosną 1954 r. ponad 10 osób zostało zatrudnionych w nowym Instytucie. Jestem dziś bodaj ostatnim aktywnym pochodzącym z tego zaciągu.

Muszę podkreślić, że pisząc tę historię powojenną polskiej geografii przeżywam podwójnie te lata, zarówno czując się świadkiem, jak i uczestnikiem sukcesów inspirowanych przez naszych nauczycieli i szefów. Podziwiam ich zapał, wizję rozwoju i zgodne współdziałanie, którego nam czasem brakuje.

\section{Służba praktyce w badaniach geografii fizycznej}

Do różnych placówek naukowych zwracano się o opracowanie wytycznych do planów zagospodarowania jednostek administracyjnych, zwykle pod kątem rolnictwa i budownictwa. Taką rolę spełniały też przedsiębiorstwa, jak np. Geoprojekt, który zatrudniał geografów. W 1954 r. plenum KC PZPR poświęcone gospodarce rolnej zwróciło się do uczonych różnych dziedzin o przygotowanie postulatów. Geografowie przygotowali tom Przeglądu Geograficznego. Otrzymałem polecenie opracowania geomorfologicznej mapy bonitacyjnej dla rolnictwa. Była to moja pierwsza publikacja naukowa. Później podobne mapy pod kątem użytkowania i budownictwa wykonywano powszechnie, także w ramach Komitetu Przestrzennego Zagospodarowania Kraju PAN. Wśród nich zostały wykonane mapy: geomorfologiczna, hydrologiczna i klimatyczna dla Górnośląskiego Okręgu Przemysłowego (niestety mające klauzulę poufnych lub tajnych). Innym przykładem była przygotowana wraz z mapami ocena środowiska górskiego dla rolnictwa okolic stacji naukowej w Szymbarku autorstwa E. Gila, uwzględniająca monitoring mikroklimatu, stosunków wodnych i erozji gleb (opublikowana w 1979 r.). Dowiązywało do niej opracowanie racjonalnego użytkowania ziemi w różnych typach rzeźby Karpat (Gil i Starkel, 1976).

Wśród innych opracowań aplikacyjnych na specjalną uwagę zasługują prace ośrodka poznańskiego, realizowane przez zespół T. Bartkowskiego (1970) i ośrodka warszawskiego, realizowane przez zespół J. Kondrackiego (1969). Zajmowano 
się typologią krajobrazu, ujmującą walory całego środowiska i zagrożenia związane z eksploatacją.

Badania erozji gleb były prowadzone już przed geografami na stacjach naukowych przez rolników i gleboznawców, którzy popularyzowali tą wiedzę organizując zjazdy erozjonistów. Do nich dołączył w drugiej połowie lat 50. T. Gerlach (1966), a potem inni, którzy badali procesy stokowe w Karpatach. Innym działem badań mających znaczenie praktyczne stały się badania klimatu miast i uzdrowisk, zainicjowane u schyłku lat 50. w ośrodku warszawskim i rozwinięte w studiach bioklimatu przez T. Kozłowską-Szczęsną, a także prace ośrodka krakowskiego nad mezoklimatem dolin górskich.

\section{Wyjście na pole międzynarodowe}

Niewielu z polskich geografów, 11 lat po wojnie, żyjąc w izolacji od zagranicy, pamiętało organizowany w 1934 r. w Polsce Kongres Unii Geograficznej. Również niewielu geologów i geomorfologów pamiętało wiedeński kongres Międzynarodowej Unii Badań Czwartorzędu w 1937 r.

Po śmierci Stalina, wraz ze zelżeniem przepisów wyjazdowych, po raz pierwszy w 1956 r. zaistniała możliwość wyjazdu oficjalnej polskiej delegacji na kongres Międzynarodowej Unii Geograficznej w Rio de Janeiro w Brazylii. Znaleźli się w niej m.in. J. Dylik i M. Klimaszewski. Okazało się, że skromna polska delegacja odniosła niespodziewany sukces. Polskie metody i wyniki badań wzbudziły duże zainteresowanie. Rekonstrukcja środowisk peryglacjalnych Polski środkowej poprzez analizę osadów i form, dokonana przez szkołę łódzką, zaowocowała wyborem J. Dylika na przewodniczącego Komisji Peryglacjalnej i uznaniem łódzkiego Biuletynu Peryglacjalnego za organ tej komisji. Zaprezentowana przez M. Klimaszewskiego szczegółowa mapa geomorfologiczna, owoc kartowania terenowego, ukazująca barwami genezę form i przybliżony wiek, pozwalała czytać z mapy ewolucję rzeźby. Weszła ona do programu prac Komisji Geomorfologii Stosowanej, a brytyjskie Royal Geographical Society odznaczyło go medalem Patrona. Legenda do map geomorfologicznych całego świata znalazła się w publikacji Encyclopedia of Geomorphology R. Fairbridge'a.

W 1957 r. ośmioosobowa delegacja polskich geologów czwartorzędu i geomorfologów wyjechała na Kongres Czwartorzędowy INQUA w Hiszpanii. Pochodzili oni z kilku ośrodków i prezentowali na Kongresie różnorodną problematykę m. in. ze względu na strefowość kilku zlodowaceń skandynawskich (R. Galon, J. Dylik, M. Klimaszewski, Z. Różycki, B. Krygowski i inni) oraz bogaty dorobek kartograficzny. Efektem tego było powierzenie Polsce organizacji następnego kongresu INQUA w 1961 r. W tymże 1957 r. odbyło się też w Łodzi sympozjum Komisji Peryglacjalnej MUG, które zgromadziło ponad 20 wybitnych specjalistów z całego świata i było pierwszą okazją spotkania badaczy zmarzliny syberyjskiej i amerykańskiej. Miałem 
wtedy okazję zaprezentować wyniki polskich badań w Karpatach. W lecie 1957 r., w ramach międzynarodowego Roku Polarnego, na Spitsbergen wyruszyła polska interdyscyplinarna ekspedycja pod kierunkiem S. Siedleckiego i została założona stała stacja polarna, która dała początek wyprawom dużych grup badaczy na Spitsbergen i w inne regiony Arktyki. Geografowie polscy zaczęli nawiązywać bilateralne kontakty. Prof. Leszczycki podpisał umowę z Akademią Nauk w Getyndze i umożliwił wyjazd szkoleniowy kilku młodym pracownikom IG PAN. W 1958 r. odbyłem taki wyjazd, podczas którego miałem możliwość zapoznać się z badaniami starej szkoły niemieckiej i zaprezentować nowe spojrzenie na rolę holocenu, dotąd niedocenianego.

Kongres MUG w Szwecji w 1960 r. dał szansę uczestnictwa ponad 20 uczonym z Polski. Nie były to jednak indywidualne przypadkowe wyjazdy. S. Leszczycki zadbał o to (co powtarzał w czasie przygotowania do kilku następnych kongresów), aby zaprezentować najlepsze wyniki polskich badań, obsadzić wszystkie komisje, przygotować na kongres publikacje, a także zorganizować stoisko z polskimi pracami i mapami. Dlatego już kilka miesięcy przed kolejnym kongresem na sesji Komitetu Nauk Geograficznych PAN prezentowane były referaty ze wszystkich ośrodków w kraju, wybierano z nich najlepsze do publikacji i zgłoszenia na kongres. W czasie kongresu na polskim stoisku można było zobaczyć, a nawet dostać lub kupić, polskie prace i mapy, które były prezentowane także przez inne polskie wydawnictwa kartograficzne czy geologiczne. Osobą, która organizowała ekspozycję, był sekretarz Instytutu B. Winid; przy wyjeździe rozdzielał on bagaż między młodych uczestników (S. Leszczycki dbał o to, by zdobyć środki na ich udział w kongresie). Z kongresu wracaliśmy również z wydawnictwami zagranicznymi, zdobytymi dla centralnej biblioteki w stolicy. Uczestnicy, poza ich specjalnością, byli zobowiązani uczestniczyć także w spotkaniach nieobsadzonych przez Polaków sekcji, tak aby potem móc uzyskać pełne sprawozdanie z kongresu i opublikować w kraju (zapewniał to Instytut Geografii PAN).

W czasie kilkudniowego kongresu braliśmy też udział w roboczych zebraniach interesujących nas komisji, a na krótkich spotkaniach naszej delegacji informowaliśmy o wynikach wyborów. Na sztokholmskim kongresie wybrano M. Klimaszewskiego przewodniczącym Podkomisji Kartowania Geomorfologicznego, a A. Jahna - członkiem Komisji Badania Stoków.

Od jesieni 1960 r. trwały przygotowania do VI Kongresu Unii Badań Czwartorzędu INQUA w Polsce. Odbył się on we wrześniu 1961 r. w Warszawie. Zgromadził kilkuset uczestników z całego świata. Poprzedziły go sympozja problemowe kilku komisji INQUA odbyte w kilku regionach Polski. Po kongresie ruszyła autobusami około 200-osobowa wycieczka przecinająca strefy wszystkich zlodowaceń od Bałtyku po Tatry, na której prezentowano w terenie dziesiątki stanowisk badawczych uzupełniane wystawami w ośrodkach naukowych. Po kongresie zostały wydane grube tomy wygłaszanych referatów.

Kongres INQUA był wielkim sukcesem polskiej nauki, a równocześnie sukcesem organizacyjnym, mając na uwadze powojenny stan dróg i hotelarstwo. Będąc 
razem z E. Mojskim sekretarzem na niektórych zebraniach około 30-osobowego interdyscyplinarnego komitetu organizacyjnego kongresu, byłem pełen podziwu, jak zwykle dyskutujący i konkurujący profesorowie potrafili przełamać animozje między sobą i współpracować zgodnie dla sukcesu polskiej nauki. Siedzieli obok siebie dyrektorzy instytutów uczelnianych, służb państwowych i małych laboratoriów, geolodzy i geografowie różnej specjalności, botanicy, zoologowie, archeolodzy...

Polscy badacze po ponad 2 dekadach izolacji dołączyli do światowej czołówki badaczy czwartorzędu, będąc aktywnymi w kilku komisjach INQUA. Po kongresie R. Galon został wybrany sekretarzem generalnym INQUA na okres 4 lat.

W 1962 r. odbyło się w Krakowie i Toruniu sympozjum Podkomisji Kartowania Geomorfologicznego MUG, która pod kierunkiem M. Klimaszewskiego przygotowywała treść ujednoliconej legendy do map geomorfologicznych całego świata, bazującej na doświadczeniach zespołów polskich, radzieckich, francuskich, niemieckich i węgierskich. W sympozjum brali udział geomorfolodzy z wielu krajów Europy, a także z Kanady i Afryki. Prezentowano w terenie metody kartowania w Karpatach i na obszarze ostatniego zlodowacenia.

W tymże roku Instytut Geografii PAN i Instytut Geografii Słowackiej Akademii Nauk zorganizowały Geomorfologiczne Sympozjum Karpacko-Bałkańskie, po którym powstała Geomorfologiczna Komisja Karpacko-Bałkańska, wydane zostały 2 tomy przedstawiające ewolucję rzeźby Karpat, a w 1967 r. rozpoczęliśmy wydawanie rocznika Studia Geomorphologica Carpatho-Balcanica, w którym publikowali artykuły wybitni uczeni europejscy.

Rok 1964 to Kongres Geograficzny w Londynie. Udział w nim wzięło ok. 30 osób z Polski. Polskie Towarzystwo Geograficzne zorganizowało zbiorowy wyjazd. Opublikowaliśmy zeszyt czasopisma Geographia Polonica. Polacy objęli przewodnictwo 5 komisji MUG.

Obok tego w latach 60. odbywały się bilateralne spotkania polsko-brytyjskie i polsko-francuskie, także kilka sympozjów międzynarodowych w Polsce, w tym Komisji Ewolucji Stoków MUG, której przewodniczył A. Jahn. Rozwijały się badania na Spitsbergenie i Islandii.

Uhonorowaniem polskiej aktywności był wybór S. Leszczyckiego na prezydenta MUG w czasie kongresu w New Delhi w 1968 r. W tymże roku L. Starkel zainicjował badania geomorfologiczne w Himalajach.

$\mathrm{U}$ progu lat 70., wraz z pojawieniem się nowych metod datowania na czele $z{ }^{14} \mathrm{C}$, wzrosło zainteresowanie badaniami przeszłości środowiska. W 1972 r. odbyło się w Polsce sympozjum Komisji Holocenu INQUA z wycieczką od Bieszczadów po Białowieżę, zorganizowane przez geomorfologów, geologów i paleobotaników z ośrodków krakowskiego i warszawskiego, po którym objęliśmy kierownictwo podkomisji. W niej powstał program IGCP-158 „Paleohydrologia strefy umiarkowanej w ostatnich 15000 latach" sponsorowany przez UNESCO, inicjujący rozwój nowej dyscypliny - paleohydrologii. 
W 1974 roku Zakład Krakowski IGiPZ PAN pod kierunkiem K. Klimka zainicjował kompleksowe badania przyrodnicze w górach i strefie stepowej Mongolii u południowej granicy lasu i badania wieloletniej zmarzliny, rozszerzone na kilka regionów. Przez kilka lat wzięło w nich udział kilka zespołów z różnych ośrodków. Był to drugi teren polskich ekspedycji obok Spitsbergenu, na którym od lat polskie badania konkurowały z amerykańskimi i radzieckimi stacjami polarnymi.

\section{Podsumowanie 20-letniego dorobku polskiej geografii fizycznej na II Kongres Nauki Polskiej i dalszy rozwój w dekadzie 1970-1980}

Geografowie polscy skupieni w Komitecie Nauk Geograficznych przystąpili przed Kongresem do analizy sukcesów i słabych stron oraz zarysowania kierunków przyszłych badań. W Przeglądzie Geograficznym ukazało się kilka artykułów pisanych przez przedstawicieli średniego pokolenia związanych z ośrodkiem poznańskim i Instytutem Geografii PAN.

Kierunki badań nakreślone w dekadzie powojennej zostały w większości zrealizowane, aczkolwiek okres 20-30 lat okazał się za krótki by doprowadzić do wszystkich planowanych syntez i pełnego rozwoju nowych dziedzin badań.

Niewątpliwym sukcesem była realizacja szczegółowych badań terenowych, obejmujących cały kraj, wykonywanych identycznymi metodami, które stały się podstawowym źródłem informacji zarówno o cechach środowiska przyrodniczego, jak i o różnych typach działalności człowieka. Gdy w innych krajach poszczególne jednostki i zakłady realizowały swoje hobby i często „skakały z kwiatka na kwiatek", to polscy uczeni, przetrzebieni wojną i do 1956 r. odcięci od świata, potrafili się zjednoczyć i zarazem zmusić do badań potrzebnych dla odbudowy kraju. Paradoksalnie Josef Stalin wpłynął zamknięciem granic i zmuszeniem do ujednolicenia planów 5-letnich, na rozwój nowych metod. Nie do przecenienia była jednak pozycja „króla Stasia”, głównego dyrygenta, który u schyłku lat 50-tych przeprowadził cała polską geografię przez grożące jeszcze zasieki. Oto pokrótce główne źródła sukcesu, gdy u schyłku lat 50. „wypuszczono nas z klatki”.

Podam drobny szczegół mówiący o tym, jak za granicą oceniano naszą działalność. Gdy Amerykanie organizowali w 1989 r. sympozjum na temat rozwoju światowej geomorfologii, porównując na kolejnych etapach dwóch stuleci dwie rywalizujące szkoły: amerykańską i zachodnioeuropejską, niespodziewanie zwrócili się do mnie, abym jako jedyny spoza tego kręgu, przedstawił historię polskiej geomorfologii. Nie wiedziałem co zrobić..., czy odmówić? A organizatorom zapewne chodziło o wyjaśnienie, jak do tego doszło, że mały, zniszczony wojną kraj, potrafił nagle dobić do czołówki światowej. Szkoda, że później nie dotrzymaliśmy kroku...

Porównując osiągnięcia z celami i programem zakładanym w 1952 r. i w okresie rozbudowy Instytutu Geografii PAN, możemy powiedzieć, że nie wszystko zostało 
osiągnięte. W zakresie geografii fizycznej największe sukcesy odniosły wyodrębniające się dyscypliny badające elementy środowiska. Wiele prac u schyłku lat 60. uległo jednak zahamowaniu.

Kartowanie geomorfologiczne mogło „poszczycić się” wykonaniem map w skalach 1 : 25000 lub 1 : 50000 dla 12,5\% powierzchni kraju. Ale drogi wielobarwny druk i częste zastrzeżenia "do użytku służbowego" spowodowały, że ze względów finansowych u schyłku lat 60. zahamowano ich realizację. Podobnie nie doszło do skutku porozumienie z Państwowym Instytutem Geologicznym, który w uproszczonej formie zaczął drukować je jako załączniki do zdjęcia geologicznego. Ale istniejące rękopisy stały się podstawą przeglądowej mapy opracowanej zespołowo i wydanej przez Instytut Geografii PAN oraz dwutomowej monografii "Geomorfologia Polski" wydanej w 1972 r. (Klimaszewski i Galon, 1972). Mapa stała się nieodłączną częścią dziesiątek rozpraw o ewolucji rzeźby, atlasów województw i artykułów drukowanych przeważnie w języku angielskim w dwóch wydawanych w Polsce czasopismach: Studia Geomorphologica Carpatho-Balcanica i w Biuletynie Peryglacjalnym.

Podjęty z inicjatywy M. Klimaszewskiego monitoring procesów stokowych, a później fluwialnych, realizowany był w stacjach naukowych skoncentrowanych głównie w Karpatach, z których jedna, założona w 1966 r. w Szymbarku, objęła niemal cały wachlarz procesów wymiany energii i obiegu materii. Niektóre z nich specjalizowały się w procesach fluwialnych, denudacji chemicznej czy procesach osuwiskowych. Nowe metody pomiarów czy zastosowane oryginalne aparatury pomiarowe wzbudziły zainteresowanie za granicą i stały się podstawą współpracy rozwijanej szerzej od lat 70.

Badania J. Dylika i jego szkoły, które objęły całą Polskę, pokazały typ i skalę przekształcenia rzeźby glacjalnej przez procesy peryglacjalne związane z obecnością kilku faz wieloletniej zmarzliny, poprzez szczegółowe badania osadów i struktur, które dotychczas były analizowane pobieżnie. Rekonstrukcja zmian klimatu w holocenie na podstawie badania aluwiów, w połączeniu z badaniem zmian roślinności, zwróciła z kolei uwagę na rolę holocenu w przekształcaniu środowiska, którą dotąd ograniczano do ingerencji człowieka.

Równolegle wykonywana w terenie mapa hydrograficzna (która objęła w 2 pierwszych dekadach 18,5\% powierzchni kraju), stała się jednym z podstawowych elementów w opracowaniach obiegu wody w zlewniach rzecznych. Instrukcja do mapy opracowana przez K. Wit-Jóźwik i T. Celmera, stała się podstawowym przewodnikiem hydrologicznych badań terenowych. Równolegle została opracowana przeglądowa mapa hydrograficzna Polski, wypełniając lukę w zestawie map elementów środowiska.

Zakład Geoekologii Instytutu Geografii PAN przystąpił równolegle do opracowania przeglądowych map zbiorowisk roślinnych i map roślinności potencjalnej kraju (pod kierunkiem W. Matuszkiewicza), wyręczając w tym botaników, którzy koncentrowali się najczęściej na badaniach flory parków narodowych. 
W ramach geografii rozwijała się klimatologia. Prowadzono badania nad bilansem cieplnym i mikroklimatem, bazując na stacjach badawczych. Równolegle ukazało się kilka pierwszych monografii dotyczących klimatu dolin górskich, miast, uzdrowisk, otoczenia zbiorników wodnych - głównie wykonanych w ośrodku krakowskim i warszawskim. Rozwinęła się bliska współpraca z krajami sąsiednimi (w ramach $\mathrm{RWPG}$ ).

Kompleksowe opracowania elementów środowiska jednostek przyrodniczych lub administracyjnych podejmowano m.in. w Warszawie i Poznaniu. Również Zakład Ochrony Przyrody PAN i parki narodowe organizowały interdyscyplinarne zespoły badawcze publikując monografie, a nawet atlasy (np. Tatrzański Park Narodowy).

Kartowanie i monitoring różnych zjawisk był prowadzony na dużą skalę przez stałą i sezonowe stacje badawcze na Spitsbergenie, dokumentujące m.in. recesję lodowców związaną z globalnym ociepleniem. Badania te wniosły też wiele w poznanie procesów deglacjacji, których ślady rejestrujemy w dzisiejszych krajobrazach Polski.

\section{Dążenie do syntez i przecieranie nowych szlaków w latach 80.}

Przeglądowe mapy Polski, przedstawiające zarówno elementy środowiska, jak i różne typy działalności człowieka i jego ingerencji w środowisko, były u schyłku lat 70. przeważnie gotowe lub zaawansowane, co wskazywało, że dorośliśmy do syntez. Równocześnie utwierdzaliśmy się w przekonaniu, że w badaniach geograficznych obok przestrzeni musimy uwzględniać parametr czasu (Starkel, 1999). Korzenie otaczającego nas środowiska (z gospodarującym człowiekiem włącznie) tkwią w przeszłości często odległej. Jeśli chcemy służyć potrzebom społecznym i gospodarczym to okazuje się, że musimy uczestniczyć w opracowywaniu prognoz. Aby to czynić, niezbędne jest zarówno poznanie mechanizmów zachodzących dziś procesów, jak też odczytanie długookresowych trendów z badań przeszłości. W sytuacji kurczących się zasobów i postępujących zmian klimatycznych, nieuchronnych także w skali globalnej, instytucje państwowe i społeczeństwo wymagają od naukowców formułowania prognoz zmian.

W latach 70. zrozumieli to związani z gospodarką przedstawiciele nauk technicznych i rolniczych. Do badania przyrodniczych podstaw prognoz przystępowały nauki biologiczne (zwłaszcza ekologia), a nawet geologia, z zasady badająca przeszłość. Tymczasem nauki geograficzne były zapóźnione. A właśnie geografia jest nauką (lub grupą nauk), która obejmuje (a przynajmniej powinna obejmować) całość procesów zachodzących w przyrodzie na Ziemi w połączeniu z działalnością człowieka (analizując je na ogół w układzie przestrzennym).

W latach 70. badania dotyczące gospodarowania zasobami przyrody i funkcjonowania środowiska znajdowały się często w rękach przedstawicieli nauk in- 
żynieryjnych (stosowanych) i częściowo nauk biologicznych (nieobejmujących elementów abiotycznych). Dostrzegając to Komitet Nauk Geograficznych PAN i dyrekcja Instytutu Geografii PAN wystąpiły w 1980 r. z inicjatywą uruchomienia w latach 1981-1990 dwóch programów międzyresortowych, w których uczestniczyłyby uczelniane instytuty geografii. Pierwszy z nich miał obejmować problematykę środowiska geograficznego (geografia fizyczna), a drugi - gospodarki przestrzennej (geografia społeczno-ekonomiczna). Zostałem powołany na przewodniczącego zespołu koordynacyjnego pierwszego programu. Zespół składał się z przedstawicieli kilku dyscyplin cząstkowych z trzech ośrodków. W jego skład wchodzili: I. Dynowska, A. Kotarba, A. Kostrowicki, S. Kozarski, J. Paszyński i sekretarz J. Słupik, później R. Soja. Program otrzymał nazwę Przemiany środowiska geograficznego Polski. Brało w nim udział około 150-200 osób z całej Polski (Starkel i Soja, 1986). Nie ograniczał się on tylko do badań współczesnych procesów na podstawie monitoringu obiegu materii i wymiany energii na stacjach terenowych, ale również objął studia nad zmianami geoekosystemów w przeszłości. Do programu włączyli się także przedstawiciele innych dyscyplin, działających poza strukturami organizacyjnymi geografii (gleboznawstwo, geologia, botanika). Stacje monitoringu z Szymbarkiem na czele stały się podstawą podjęcia przez A. Kostrzewskiego inicjatywy utworzenia sieci monitoringu krajowego, która została przekształcona w służbę państwową rejestrującą procesy kształtujące typowe geoekosystemy na terenie kraju.

Jedną z syntez programu miała być opracowana przez zespół około 25 specjalistów monografia "Geografia Polski - środowisko przyrodnicze” której tłem miały być korzenie obecnego środowiska tkwiące w przeszłości (Starkel, 1990). Obok syntez program ten miał na celu doprowadzić do ponownego zbliżenia warsztatów geografów fizycznych z różnych ośrodków, jak też do bliższej współpracy dyscyplin "cząstkowych", które, jak geomorfologia czy klimatologia, wychodziły coraz częściej spod skrzydeł geografii (także na polu międzynarodowym). Stanęliśmy przed potrzebą ponownego zdefiniowania pojęcia geografii jako nauki, a także określenia relacji nie tylko między geografią fizyczną a ekonomiczną, ale też relacji do innych nauk o Ziemi.

Okazuje się, że zarówno do pełnej rekonstrukcji zmian w przeszłości, jak i do poznania współczesnego obiegu materii, a tym bardziej do prognozowania zmian w środowisku i dostosowania do nich gospodarki człowieka, wiedzie dziś jedyna droga poprzez badania interdyscyplinarne.

\section{Piśmiennictwo}

Bartkowski T., 1990, Wielkopolska i Środkowe Nadodrze, PWN, Warszawa.

Galon R., 1954, Rozwój geografii fizycznej, Przegląd Geograficzny, 26, 3, s. 32-52.

Gerlach T., 1966, Współczesny rozwój stoków w dorzeczu górnego Grajcarka (Beskid Wysoki - Karpaty Zachodnie), Prace Geograficzne IG PAN, 52, IG PAN, Warszawa. 
Gil E., Starkel L., 1976, Complex physico-geographical investigations and their importance for economic development of flysch Carpathian area, Geographia Polonica, 34, s. 47-61.

Klimaszewski M., Galon R., 1972, Geomorfologia Polski, PWN, Warszawa.

Kondracki J., 1969, Fizyczno-geograficzna regionalizacja Polski, Prace Geograficzne IG PAN, 69, IG PAN, Warszawa.

Kozarski S., 1973, Osiqggnięcia i ogólne założenia perspektywicznego rozwoju geografii fizycznej w Polsce, Przegląd Geograficzny, 45, 3, s. 459-472.

Kukliński A., Chojnicki Z., Grzeszczak J., Kozarski S., 1974, Nauki geograficzne i przestrzennego zagospodarowania kraju - osiagnięcia i perspektywy rozwoju, Przegląd Geograficzny, 46, 1, s. 3-28.

Leszczycki S., 1953, Stan geografii w Polsce i perspektywy jej rozwoju, Przegląd Geograficzny, 23, s. 1-54.

Leszczycki S., 1954, Dorobek geografii polskiej oraz drogi jej rozwoju w Polsce Ludowej, Przegląd Geograficzny, 26, 3, s. 3-31.

Starkel L. (red.), 1990, Geografia Polski. Środowisko przyrodnicze, PWN, Warszawa.

Starkel L., 1971, Perspektywy badań nad analizq i ocenq środowiska geograficznego Polski, Przegląd Geograficzny, 43, 3.

Starkel L., 1973, Refleksje o perspektywach geografii, Czasopismo Geograficzne, 44, 3-4, s. 445-446.

Starkel L., 1999, Space and time scales in geomorphology, Zeitschrift für Geomorphologie, Suppl.-Bd., 115, s. 19-33. 